\title{
Prevalence of Bovine Trypanosomosis and Its Associated Risk Factors in Nano and Gudeya Bila Districts of Oromia Regional State, Ethiopia
}

\author{
Gelaye Gebisa ${ }^{1 *} \quad$ Seid Ali $^{1} \quad$ Oda Gizaw $^{2} \quad$ Dawit Chala $^{3}$ \\ 1.School of Animal and Range Sciences, Hawassa University, Ethiopia \\ 2.Department of Animal Science, Mettu University, Ethiopia \\ 3. National Tsetses and Trypanosomiasis Investigation and Control Centre, Bedele, Ethiopia
}

\begin{abstract}
The prevalence of bovine trypanosomosis, the influence of associated risk factors and relative abundance of tsetse fly was investigated using 891 randomly selected cattle in Nano and Gudeya Bila districts of Oromia regional state, Ethiopia. Blood samples were collected from ear vein and examined by using Buffy coat technique and hematological procedures. The overall prevalence of trypanosomosis was found to be $2.69 \%, 95 \% \mathrm{CI}$. The relative prevalence based on Trypanosome species was $1.79 \%$ and $0.90 \%$ for T. congolense and T. vivax, respectively. The analysis for the associated risk factors revealed significant difference $(\mathrm{P}<0.05)$ in the occurrence of trypanosomosis among different districts, anemic status and body condition of examined animals. However, no significant difference was observed in trypanosomosis prevalence between age and sex groups $(\mathrm{P}>0.05)$. The mean PCV values of trypanosomosis positive $(21.92 \%)$ were significantly lower to that of negative animals $(27.44 \%)$.The apparent density of tsetse fly was $1.08 \mathrm{fly} /$ trap/day. Three species of Glossina including G. Fuscipes (70.0\%), G. Palidipes $(19.23 \%)$ and G. morsistans $(10.77 \%)$ were captured from the 120 odor baited traps. Therefore, more attention should be given to lessen the pervasiveness of this vector and impact of the disease in the study districts.
\end{abstract}

Keywords: Glossina, PCV, Risk Factors, T. Congolense, Trypanosomosis, Tsetse Fly

DOI: $10.7176 / \mathrm{JBAH} / 10-15-05$

Publication date:August $31^{\text {st }} 2020$

\section{Introduction}

Ethiopia has the largest livestock inventories in Africa, including about 59.5 million head of cattle and 60.90 million sheep and goats population according to the survey reported by CSA (2018). Although livestock are the backbone of the rural economy, diseases like African Trypanosomiasis are eminent restraints to livestock production and productivity in many regions of Ethiopia (Kumela et al., 2018). Trypanosomes transmitted by tsetse flies are endemic in a part of sub-Saharan Africa (SSA) called the tsetse fly belt. In Ethiopia, the disease is more prevalent in the southern and western regions where the primary vector exists and it remains as one of the largest causes of livestock production losses. Tsetse fly (Glossina species) has a prominent economic impact as the biological vectors of trypanosomes (Tesfaheywet and Abraham, 2012; Kumar et al., 2012). The most prevalent trypanosome species are T. congolense, $\mathrm{T}$. vivax and $\mathrm{T}$. brucei with a wide host range among domesticated animals (Abebe 2005). This prevalence varies depending on agro-climatic conditions, season of year, host preferences or virulence for different species and interventions done to control the impact of the disease (Abebe and Jobre, 1996; Leta et al., 2016).

In Ethiopia, bovine trypanosomosis is widely distributed in western and south-western parts of the country (Abebe, 2005; Leta et al., 2016; Kumela et al., 2018). Bovine trypanosomosis was very importance in regards to economic point views (Meberate et al., 2000). According to Leta et al. (2016) it is estimated that about 10 to 14 million heads of cattle in Ethiopia are exposed to the risk of trypanosomosis. The disease results in loss of livestock and agricultural productivity with severe socio-economic impacts (Mengistu et al., 2019). Trypanosomosis reduces work efficiency of oxen and discourages the introduction of drought animals in to crop farming (Omotainse et al., 2004). It is also a cause for severe and frequently fatal disease of livestock mainly in the poor rural community and it is fairly considered as a foot root cause of poverty in Ethiopia (Abebe, 2005). Among the total regions of Ethiopia, Amhara, Benishangul Gumuz, Gambella, Oromia and SNNPR regions are mostly infected with more than one species of Tsetse flies (Keno, 2005; Tesfaye, 2002). Although livestock trypanosomosis is a well-known constraint to livestock production, its prevalence and the associated risk factors were not well documented in Nano and Gudeya Bila districts. Thus, the major objective of this study was to assess the prevalence of bovine trypanosomosis, the influence of associated risk factors and relative abundance of tsetse fly in Nano and Gudeya Bila districts of Oromia Regional State, Ethiopia. 


\section{Material and Methods}

\subsection{Description of the study area}

The study was conducted in five peasant associations (PAs) of Gudeya Bila and Nano districts of Oromia Regional State, Ethiopia. Gudeya Bila district is one of the 17 districts located in the East Wollega Zone of Oromia Regional State of Western part of Ethiopia. It is situated at $277 \mathrm{~km}$ far away from capital city, Addis Ababa towards West direction and encompasses agro-ecologies of highland, mid-altitude and lowland with proportion of $17.6 \%$ and $55.8 \%$ and $26.6 \%$, respectively. Rainfall is bi-modal, ranging from 1400 to $2000 \mathrm{~mm}$ annually with temperature ranges of 11 to $23^{\circ} \mathrm{C}$. The farming system in the district is mainly mixed crop-livestock production. Maize, sorghum, wheat, and teff, barley, and Niger seed are the dominant cereal crops cultivated in the area (CSA, 2018). Nano district is also one of the districts located in the South West Showa Zone of Oromiya Region, Ethiopia. The area is situated at about 230km South West of Addis Ababa within the altitude range of 1500-1600 meters above sea level bordering the Ghibe river system. The district is located at latitude $80^{\circ} 50^{\prime} \mathrm{N}$ and longitude $37^{\circ} 45^{\prime} \mathrm{E}$. Total area coverage of the district is about 50,000 hectares and the weather condition is characterized by sub-humid climate and a moderately hot temperature with a mean annual temperature of $20^{\circ} \mathrm{C}$. The highest average monthly temperature occurs in January with mean maximum temperature of $28^{\circ} \mathrm{C}$. The lowest monthly temperature occurs in August with average monthly minimum temperature of $12^{\circ} \mathrm{c}$. It receives high and reliable annual rain fall averaging $1100 \mathrm{~mm}$ /annum with low inter annual variation. Among the livestock species, bovine and caprine are the predominant species in this district and they have been dependent upon communal grazing field as a feed source and watering points are the tributaries of large rivers. Livestock crop (mixed) farming system is the dominant farming system in this area.

\subsection{Study Design}

A cross sectional study was conducted to determine the prevalence of bovine trypanosomosis in Gudeya Bila and Nano districts of Oromia Regional state, in study period between from $5^{\text {th }}$ of March, 2019 to $25^{\text {th }}$ of June 2019. The study was constituted the local cattle of different age groups, body condition scores and both sex groups of cattle from the selected districts. The age of the cattle was determined according to the definition characteristics (Pasquini et al., 2003) and information from owners of the cattle. The body condition was scored using the method described by Nicholson and Butterworth (1986).

\subsection{Sample Size Determination and Sampling strategies}

Multi stage random and proportional purposive sampling techniques were employed to select the representative animal from the study areas. Random sampling method was employed to select both Gudeya Bila and Nano districts among the districts of Western part of Oromia Region, Ethiopia. Nano Halo, Halo Dinki, Biftu Jalala, Haro Gudisa and Zangi were the peasant associations (PA's) involved as a study site during the study periods. A proportional purposive sampling method was employed to select the peasant associations (PA's). Among the (PA's) mentioned above, the first three of them were selected from Nano district and the last two of them from Gudeya Bila based on the density of cattle population. Finally, the studied animals were selected using simple random sampling techniques.

The number of animals required for the study was assessed using the formula given by Thrusfield (2007) for simple random sampling.

$$
\left.\mathrm{N}=\frac{1.96^{2} * \mathrm{P}}{\mathrm{d}^{2}} \exp \underline{(1-\mathrm{P}} \exp \right)
$$

Where, $\mathrm{N}=$ required sample size, $\mathrm{P}_{\exp }=$ expected prevalence, $\mathrm{d}=$ desired absolute precision

The sample size determination was using $95 \%$ level of confidence, $50 \%$ expected prevalence since there was no previous study conducted in Nono and Gudaya Bila districts and 0.05 desired absolute precision. The sample size would be 384 cattle based on the formula; however, 891 cattle were examined to increase the precision of the study.

\subsection{Study Methodology and Procedures \\ 2.4.1. Buffy Coat Technique}

Blood was collected from an ear vein using heparinized micro-haematocrit capillary tube and the tube was sealed. A heparinized capillary tube containing blood was centrifuged for $5 \mathrm{~min}$ at $12,000 \mathrm{rpm}$. After the centrifugation, trypanosomes were usually found in or just above the buffy coat layer. The capillary tube was cut using a diamond tipped pen $1 \mathrm{~mm}$ below the buffy coat to include the upper most layers of the red blood cells and $3 \mathrm{~mm}$ above to include the plasma. The content of the capillary tube was expressed on to slide, homogenized on to a clean glass slide and covered with cover slip. The slide was examined under $40 \mathrm{X}$ objective and $10 \mathrm{X}$ eye pieces for the movement of parasite (Thrustfield, 2005).

\subsubsection{Thin Blood Smear}

The trypanosome species were identified using Giemsa-stained thin blood films. A small drop of blood from a 
microhaematocrit capillary tube to the slide was applied to a clean slide and spread by using another clean slide at an angle of $45^{\circ}$, air dried and fixed for 2 min in methyl alcohol, then immersed in Giemasa stain (1:10 solution) for $50 \mathrm{~min}$. Drain and wash of excess stain using distilled water, allowed to dry by standing up right on the rock and examined under the microscope with oil immersion objective lens. This technique is the most sensitive of the parasitological tests for the detection of T. vivax and T. congolense (Murray et al., 1977; Murray et al., 1983).

\subsubsection{Measuring of Packed Cell Volume (PCV)}

Blood samples were obtained by puncturing the marginal ear vein with a lancet and collected directly into a capillary tube. The capillary tubes were placed in micro haematocrit centrifuge with sealed end outer most. The tube was loaded symmetrically to ensure good balance. After screwing the rotary cover and closing the centrifuge lid, the specimens were allowed to centrifuge at 12,000 rpm for $5 \mathrm{~min}$. Tubes were then placed in haematocrit and the readings were expressed as a percentage of packed red cells to the total volume of whole blood. Animals with $\mathrm{PCV} \leq 24 \%$ were considered as anemic (Van den Bossche et al., 2000).

\subsection{Entomological Survey}

The apparent densities of tsetse flies were determined based on the mean fly catches in odors baited traps. Mixtures of Acetone, Octenol and cow urine were used as a bait to attract the flies. A total of 120 (110 Monopyramidal, 4 NGU and 6 Biconical traps) were positioned in five peasant association of the selected two districts at an approximate interval of 100 to $200 \mathrm{~m}$ for 48 hours in watering and grazing points in which the fly and the vector are believed to have frequent contacts. The flies caught per trap were identified, counted and the apparent fly density per trap per day $(\mathrm{f} / \mathrm{t} / \mathrm{d})$ was recorded.

\subsection{Data Analysis}

The collected data was analyzed using SPSS (version 20:0). Descriptive statistics was employed to measure the prevalence trypanosomosis and existing parasite species in the study areas. The Chi-square test was employed to test the significant difference in prevalence of trypanosomosis in association to the risk factors such as sampling areas (districts), age, body condition, sex and anemic status of the studied animals. Independent t-test was utilized to compare the mean PCV values of the parasitemic and aparasitemic animals. Single factor ANOVA was employed to test the mean PCV values of animal infected with different parasite species and non-infected animal. Differences between parameters were tested for significance at probability levels of $\mathrm{P}<0.05$ and $95 \%$ confidence interval. The apparent density of the tsetse fly was calculated as the number of tsetse catch/trap/day using a descriptive statistics.

\section{Results}

\subsection{Prevalence of Trypanosome and Parasite Species}

The overall prevalence of trypanosome and parasite species in the study areas were shown in Table 1. Out of the 891 of cattle examined, only 24 animals were found positive for trypanosomosis and the prevalence in each district was $5.35 \%$ (23/430) for Nono and $0.22 \%$ (1/461) for Gudeya Bila district. Prevalence, hence, is 2.69\% (24/891), 95\% CI and the relative prevalence based on Trypanosome species was $1.79 \%(16 / 891)$ and $0.90 \%(8 / 891)$ for T. congolense and T. vivax, respectively.

\subsection{Prevalence of Trypanosome and Effect of Associated Risk Factors}

The prevalence of trypanosome and effect of associated risk factors in the study areas were presented in Table 2. The analysis for the associated risk factors revealed significant difference in the occurrence of trypanosomosis among different districts, anemic status and body condition of examined animals $(\mathrm{P}<0.05)$. However, the prevalence of trypanosome infections did not differ $(\mathrm{P}>0.05)$ between sexes and age categories (figure-1).

\subsection{PCV Value of Aparasitaemic and Parasitaemic Animals}

In this study, the average PCV of the animals infected with trypanosomes was $21.92 \pm 0.73 \%$ (Table 3). It was significantly lower $(\mathrm{P}<0.05)$ than the average $\mathrm{PCV}$ of the animals that were parasitological negative $(27.44 \pm$ $0.19 \%)$.

\subsection{Entomological Survey Results}

A total of 520 Glossina flies were caught from 120 odors baited traps deployed for two consecutive days at 5 PAs (kebeles) in two study districts. Almost all, 99.42\% (517/520) of the tsetse flies were captured from Nano district (Table 4).The apparent density of tsetse flies captured in the area was $1.08 \mathrm{fly} /$ trap/day. Out of the total caught 520 tsetse flies, 364, 100 and 56 were Glossina Fuscipes, Glossina Palidipes and Glossina morsistans, respectively. Higher proportion, $73.85 \%$ (384/520) were females and the rest, 26.15\% (1236/520) of them are male tsetse flies. 


\section{Discussion}

\subsection{Prevalence of Trypanosome}

The overall prevalence of bovine trypanosomosis in the study area was $2.69 \%$, which was lower in contrast to the reports of other authors elsewhere in the country as shown in Table 5. However, a study by Tamiru et al. (2016) indicated that the prevalence of caprine trypanosomosis is only $1 \%$ in Nono district. The possible suggestion may be due to the interventions done to control the impact of the disease through Bedele National Tsetse and Trypanosomiasis Investigation and Control Centre (BNTTICC).

\subsection{Trypanosome Species}

Amongst the trypanosome species, T. congolense (66.67\%) and T. vivax (33.33\%) were detected in this study. Infection due to $\mathrm{T}$. brucei or mixed infections were not noted. A similar proportional trend was shown in previous reports. For instance, T. congolense $(72.73 \%)$ and T. vivax $(27.27 \%)$ were detected in a study by Tafese et al. (2012). Similarly Bitew et al. (2011) found T. congolense $(54.3 \%)$ followed by T. vivax (45.7\%). Bezabih and Bisho (2017) also found T. congolense (60.3\%), T. vivax (27.6\%) and 12.1\% mixed infection at Ouba Debrestahay District of Gamogoffa Zone, Southern Ethiopia. Kumela et al. (2018) also reported that T. Congolense (61.83\%), T. vivax $(26.83 \%)$ and T. brucei $(12.75 \%)$ were species causing cattle trypanosomosis in Western Ethiopia. However, Mihret et al. (2007) reported T. vivax as the predominant species identified (90.5\%) followed by T. congolense $(4 \%)$ while the remaining $(5.5 \%)$ were mixed infection. The discrepancy might be due to the differences in on agro-climatic conditions, season of year and interventions done to control the impact of the disease (Abebe and Jobre, 1996; Leta et al., 2016).

\subsection{Associated Risk Factors and PCV}

The analysis for the associated risk factors revealed that there was a significant difference in trypanosome prevalence between the study sites $(\mathrm{P}<0.05)$. Almost all, 99.42\% $(517 / 520)$ of the tsetse flies were captured from Nano district. The altitude of the district ranges from 1375 to 1500 masl. This could favor the presence of suitable habitat for the vectors which results in high fly density. Animals with poor body condition were more victimized for the disease as compared with animals with good body condition scores. Abebayehu \& Biniam (2010), Melkamu et al. (2017) and Feyisa et al. (2019) also reported higher infection rate of trypanosomiasis for poor body conditioned animals than good to medium conditioned animals. The higher rate of infection for those poor conditioned and emaciated animals might be attributed to their reduced immunity for the diseases.

In this study, the prevalence of trypanosomiasis was not significantly affected by sex $(\mathrm{P}>0.05)$. This shows that both male and female cattle were equally susceptible to trypanosomosis infection. Similarly Daya and Abebe (2008), Abebayehu \& Biniam (2010) and Melkamu et al. (2017) observed no significant difference in trypanosome infection between males and females. However, Magona et al. (2008) and Kumela et al. (2018) observed higher prevalence in male than in female animals. The present finding confirms that trypanosomosis is not sex linked.

Trypanosome infection among the different age groups indicated insignificant during the study period, but higher for four year old animals. This finding was in line with Kumela et al (2018) who observed a similar trend as trypanosomosis is not affected by age group of animals. In contrary to the present finding Abebayehu \& Biniam (2010) and Melkamu et al. (2017) reported trypanosome infection was more in older cattle compared to young animals.

The present study revealed that anaemic animals were more susceptible to the trypanosomosis infection and the average PCV of the animals infected with trypanosomes was higher than for those of negative animals. This finding was in line with the previous findings of Feyisa et al. (2019). PCV is the most reliable indicator of anaemia in Trypanosomosis (Murray, 1978; Morrison et al., 1981). Several studies reported that Trypanosomosis caused depressed PCV levels in infected animals (Abebe, 2005; Mihret et al., 2007; Marcotty et al., 2008; Bizuayehu et al., 2012).

\subsection{Entomological Survey}

During the entomological survey, 520 tsetse flies were caught with the apparent density of $1.08 \mathrm{fly}^{-1} \operatorname{trap}^{-1} \mathrm{day}_{\text {. This }}$ finding was relatively higher than previous report of Melkamu et al. (2017) which was $0.83 \mathrm{flies}^{-1}$ trap $^{-1}$ day in $^{-1}$ Edja district of Guraghe zone. Abebayehu \& Biniam (2010) also reported $2.83 \mathrm{flies}^{-1}$ trap $^{-1}$ day in Bench Maji zone, South Western Ethiopia. However, Lelisa et al. (2014), Kumela et al. (2018) and Kassaye (2015) reported fly densities of 10.5, 11.98 and $13.01 \mathrm{fly} /$ trap/day from western part of Ethiopia. G. Fuscipes (70.0\%), G. Palidipes $(19.23 \%)$ and G. morsistans (10.77\%) species of Glossina were identified from the area. Similarly Abebayehu \& Biniam (2010) and Melese et al. (2017) detected G. Fuscipes and G. Palidipes as the dominant tsetse fly species. It had been reported that the Glossina species has a prominent economic impact as the biological vectors of trypanosomes (Kumar et al., 2012; Tesfaheywet and Abraham, 2012). In this study, female (73.85\%) flies were more in number than male tsetse flies (26.15\%) which supports the previous study of Melkamu et al. (2017). This might be attributed to the fact that females live longer lifespan than males as previously stated by lehane (2005) 
and Kumela et al. (2018).

\section{Conclusions}

The result of the present study revealed that trypanosomosis is one of the problematic factors for poor agricultural activity and low production from animal in both Nono and Gudeya Bila districts. The most prevalent parasite species in the study area was T. congolense and T. vivax and the infections significantly affect the PCV values and body condition of the animal. The Glossina species particularly G. Fuscipes, G. Palidipes and G. morsistans had a prominent economic impact as the biological vectors of trypanosomes. Therefore, appropriate control measures and providing treatments based on the veterinarian recommendations should be taken to improve livestock productivity in the study areas, especially at Nono district.

\section{Conflict of Interests}

The authors declare that they have no competing interest

\section{References}

Abebayehu Tadesse \& Biniam Tsegaye. 2010. Bovine trypanosomosis and its vectors in two districts of Bench Maji zone, South Western Ethiopia. Trop Anim Health Prod, 42:1757-1762. DOI 10.1007/s1 1250-010-96320 .

Abebe, G. and Jobre, Y. 1996. Trypanosomiasis: A treat to cattle production in Ethiopia. Revue de Médecine Vétérinaire, 147:897-902.

Abebe, G. 2005. Trypanosomosis in Ethiopia. Ethiopian Journal of Biomedical Science, 4(1): 75-121.

Achenef M, Admas A. 2012. Bovine Trypanosomosis and Its Vector Type and Density at Debre Elias District, North-western, Ethiopia. J. Advan. Vet. Res. 2:247-251.

Adane Mihret and Gezahagne Mamo. 2007. Bovine Trypanosomosis in three districts of East Gojjam Zone bordering the Blue Nile River in Ethiopia, J Infect Developing Countries 2007; 1(3): 321-325.

Bitew M, Amedie Y, Abebe A. 2011. Prevalence of bovine trypanosomosis in selected areas of Jabi Tehenan district, West Gojam of Amhara regional state, north western Ethiopia. African Journal of Agricultural Research, 6(1): 141-144.

Bizuayehu A, Basaznew B, Tewodros F and Mersha C. 2012. Bovine trypanosomosis: A threat to cattle production in Chena district, Southwest Ethiopia .Open Journal of Animal Sciences 2(4): 287-291.

CSA (Central statistical Authority) (2018). Livestock Population of Ethiopian. Central Statistical Authority, Addis Ababa, Ethiopia.

Daya, T. and Abebe, G., 2008. Seasonal Dynamics of Tsetse and Trypanosomosis in selected sites of Southern Nation, Nationalities and Peoples regional State, Ethiopia. Ethiopian Veterinary Journal, 12 (2): 77-92.

Desta M. 2014. Trypanosome infection rate of Glossina morsitans and trypanosomosis prevalence in cattle in upper Didessa valley western Ethiopia. Int J Curr Microbiol App Sci 3(3): 378-388.

Feyissa B, Samson A, Mihreteab B. 2011. Bovine Trypanosomosis in Selected Villages of Humbo District, Southern Ethiopia. Glob.Vet. 7(2):192-198.

Kassaye, B.K., 2015. Prevalence of Bovine Trypanosomosis and Apparent Density of Tsetse Flies in Sayonole District Western Oromia, Ethiopia. J Veterinar Sci Technol., 6: 254.

Keno M. 2005. The Current Situation of Tsetse and Trypanosomiasis in Ethiopia, Ministry of Agriculture and Rural Development, Veterinary Service Department, in Proceeding of 28th Meeting of International Scientific Council for Trypanosomiasis Research and Control (ISCTRC).

Kumar H, Gupta MP, Sidhu PK, Mahajan V, Bal MS, Kaur K, Ashuma VS, Singla LD. 2012. An outbreak of acute Trypanosoma evansi infection in crossbred cattle in Punjab, India. J. Appl. Anim. Res. 40(03):256-259.

Lehane, M.J. 2005. The Biology of Blood-Sucking in Insects, second edition, Liverpool School of Tropical Medicine, Cambridge University Press, The Edinburgh Building, Cambridge, UK.

Lelisa, K., S.Shimelis, J.Bekeleand D. Shiferaw. 2014. Bovine trypanosomosis and its fly vectors in three selected settlement areas of Hawa-Gelandistrict, western Ethiopia. Onder J Vet Research, 81(1): 715.

Leta, S., Alemayehu, G., Seyoum, Z. et al. 2016. Prevalence of bovine trypanosomosis in Ethiopia: a metaanalysis. Parasites Vectors 9, 139 doi: 10.1186/s13071-016-1404-x.

Magona, J. W., Walubengo, J. and Origin, J. T. 2008. Acute haemorrhagic syndrome of bovine trypanosomosis in Uganda. Acta Tropica. 107, 186-191.

Mamoudou A., Zoli A., Mbahin N., Tanenbe C., Bour-Danne, Clausen P.H., Marcotty T., Van Den Bossche P.,Geerts S. 2006. Prevalence and incidence of bovine trypanosomosis onthe Adamaoua plateau in Cameroon 10 years after the tsetse eradication campaign. Vet. Parasitol., 142, 16-22.

Marcotty T, Simukoko H, Berkvens D, Vercruysse J, Praet N, et al. 2008. Evaluating the use of packed cell volume as an indicator of trypanosomal infections in cattle in eastern Zambia, Preventive Veterinary Medicine, 87(34): 288-300. 
Meberate A, Menjeta B, Vreysen M, Bencha B, Woldyes G. 2000. The distribution and relative abundance of tsetse flies in the Southern Rift valley of Ethiopia. OAU/SCTRS publication 120: 202-213.

Megersa L, Feyisa B, Dereje A, Behablom M. 2019. Prevalence of Bovine Trypanosomosis and Apparent Density of Tsetse Fly in Botor Tolay District, Jimma Zone, Ethiopia. Biomed J Sci \& Tech Res 13(3): 9976-9983. DOI: 10.26717/ BJSTR.2019.13.002401.

Melkamu Melese, Sisay Alemu, Jelalu Kemal, Yimer Muktar and Ashebr Abraha, 2017. Vector identification and bovine trypanosomosis in Edja district, south Ethiopia. Livestock Research for Rural Development 29 (5) 2017.

Mengistu A, Gelaye G, Oda G, Endalu M,Wahid M. A (2019). Opportunity and Constraints of Cattle Production System in Three Selected Districts of Ilu Aba Bor Zone, Ethiopia. J Global Veterinaria 21 (2): 93-99. DOI: 10.5829/idosi.gv.2019.93.99.

Migbaru Keffale Bezabih and Mabure Shille Bisho. 2017. Prevalence of bovine trypanosomiosis in Gamogoffa Zone, Ouba Debrestahay District, Southern Ethiopia. Journal of Veterinary Medicine and Animal Health, Vol. 9(9), pp. 250-254. DOI: 10.5897/JVMAH2015.0421.

Morrison WL, MM, MMWI. 1981. Bovine Trypsnosomosis. In: Ristic Mand Mclntyre, 1st edn. Pp: 486-488.

Murray M. 1978. Anemia of Bovine African Trypanosomiasis: An overview. In Pathogenicity of trypanosomes: proceedings of a workshop, IDRC, Ottawa, ON, CA, pp: 121-127.

Murray, M., Murray, P. K. and McIntyre, W. I. M. 1977. An improved parasitological Technique for the diagnosis of African trypanosomiasis. Transactions of the Royal Society of Tropical Medicine and Hygiene. 71: 325326.

Murray, M., Trail, J. C., Turner, D. A. and Wissocq, Y. 1983. Livestock productivity and Trypanosomosis network manual, ILCA, Addis Ababa.Pp.127.

Nicholson, M. J. and Butterworth, M. H. 1986. A Guide to condition scoring of zebu cattle. ILCA, Addis Ababa Ethiopia.

Omotainse SO, Kalejaiye JO, Dede P, Dada AJ. 2004. The current status of tsetse and animal trypanosomiasis in Nigeria. J Vet Sci. 1:1-9.

Pasquini, C., T. Spurgeno and S. Pasquini, 2003. Anatomy of domestic animals: Systematic and regional approach. $10^{\text {th }}$ edn.Sudz.Publishin, USA, pp: 255.

Solomon, M. \& Fitta, G. 2010. 'Survey on bovine trypanosomosis and its vector in Metekel and Awi zones of northwest Ethiopia', Acta Tropica 117(2011),

$146-$ 151. http://dx.doi.org/10.1016/j.actatropica.2010.11.009, PMid:21110937

Tafese, W., Melaku, A. \& Fentahun, T. 2012. 'Prevalence of bovine trypanosomosis and its vectors in two districts of East Wollega Zone, Ethiopia’, Onderstepoort Journal of Veterinary Research 79(1), Art. \#385, 4 pages. http://dx.doi.org/10.4102/ojvr.v79i1.385

Tamiru Tilki, Dagnachew Haile Michael, Yohanis Merdasa, Biniyam Mulugeta and Shawit Kalayou. 2010. Epidemiology of trypanosomal infections of caprine in Nono district, south west showa zone Ethiopia. LRRD, 28(10).

Taye Itefa, Temesgen Zekarias and Kumela Lelisa. 2018. Bovine Trypanosomosis in Four Settlement Areas Bordering Birbir River, Dale Wabera District, Western Ethiopia. European Journal of Biological Sciences, 10 (2): 47-51. DOI: 10.5829/idosi.ejbs.2018.47.51.

Tesfaheywet Z, Abraham Z. 2012. Prevalence of Bovine Trypanosomosis in Selected District of Arba Minch, SNNPR, Ethiopia. Glob. Vet. 8(2):168-173.

Tesfaye M. 2002. Report of Trypanosome Infection Rate in G.M Murstans and G. Tachninoides in Didessa Valley from Bedele.

Thrusfield, M. 2007.Veterinary Epidemiology. 3rd Ed. Blackwell Science, Pp: 232-336.

Thrusfield, M. 2005. Veterinary Epidemiology; $3^{\text {rd }}$ edition Black well science, Oxford, pp: 233.

Van den Bossche, P., Shumba, W. and Makhambera, P. 2000. The distribution and Epidemiology of bovine trypanosomosis in Malawi. Veterinary Parasitology, 88:163-176.

Zemedkun Gona, Ayichew Teshale and Alebachew Tilahun. 2016. Study on prevalence of bovine trypanosomosis and density of its vectors in three selected districts of Wolaita Zone, Southern Ethiopia. Journal of Veterinary Medicine and Animal Health, Vol. 8(9), pp. 128-135, DOI: 10.5897/JVMAH2016.0468. 


\begin{tabular}{lcccc} 
Table 1. The overall prevalence of trypanosome and parasite species in the study areas \\
\hline Variables & Description & $\begin{array}{c}\text { Number of } \\
\text { Examined }\end{array}$ & $\begin{array}{c}\text { Number of } \\
\text { Positive }\end{array}$ & $\begin{array}{c}\text { Prevalence } \\
(\%)\end{array}$ \\
\hline Districts & Nono & 430 & 23 & 5.35 \\
& Gudaya Bila & 461 & 1 & 0.22 \\
& Total & 891 & 24 & 2.69 \\
\hline Parasite Species & T. Vivax & & 8 & 33.33 \\
& T. Congolence & & 16 & 66.67 \\
& Total & & 24 & 100.00 \\
\hline
\end{tabular}

Table 2. The prevalence of trypanosome and effect of associated risk factors in the study areas

\begin{tabular}{|c|c|c|c|c|c|}
\hline Factor & $\begin{array}{c}\text { Number of } \\
\text { Examined }\end{array}$ & $\begin{array}{c}\text { Number } \\
\text { of Positive }\end{array}$ & $\begin{array}{c}\text { Prevalence } \\
(\%)\end{array}$ & $\mathrm{X}^{2}$ & P-Value \\
\hline \multicolumn{6}{|l|}{ Study Sites } \\
\hline Nono & 430 & 23 & 5.35 & 22.355 & \multirow{2}{*}{$0.000^{*}$} \\
\hline Gudaya Bila & 461 & 1 & 0.22 & & \\
\hline \multicolumn{6}{|l|}{ Status } \\
\hline Non - Aneamic & 583 & 4 & 0.69 & \multirow[t]{2}{*}{25.932} & \multirow[t]{2}{*}{$0.000 *$} \\
\hline Aneamic & 308 & 20 & 6.49 & & \\
\hline \multicolumn{6}{|l|}{ Sex } \\
\hline Male & 499 & 17 & 3.41 & \multirow[t]{2}{*}{2.201} & \multirow[t]{2}{*}{0.138} \\
\hline Female & 392 & 7 & 1.79 & & \\
\hline \multicolumn{6}{|l|}{ Body Condition } \\
\hline Poor & 196 & 10 & 5.10 & \multirow{3}{*}{9.407} & \multirow{3}{*}{$0.009 *$} \\
\hline Medium & 512 & 14 & 2.73 & & \\
\hline Good & 183 & 0 & 0.00 & & \\
\hline \multicolumn{6}{|l|}{ Age } \\
\hline 1 year & 30 & 0 & 0.00 & \multirow{6}{*}{4.744} & \multirow{6}{*}{0.448} \\
\hline 2 years & 139 & 2 & 1.44 & & \\
\hline 3 years & 266 & 5 & 1.88 & & \\
\hline 4 years & 208 & 9 & 4.33 & & \\
\hline 5 years & 213 & 7 & 3.29 & & \\
\hline 6 years & 35 & 1 & 2.86 & & \\
\hline
\end{tabular}

$\mathrm{X}^{2}=$ Chi-Square, $\mathrm{P} \geq 0.05=$ Non-significant, $* \mathrm{P}<0.05=$ Significant

Table 3: Mean PCV value of Aparasitaemic and Parasitaemic animals in the study areas

\begin{tabular}{|c|c|c|c|c|c|c|}
\hline Variable & Description & Frequency & Mean PCV $\pm \mathrm{SE}$ & $\mathbf{t}$ & $\mathbf{F}$ & P-Value \\
\hline Result of & Infected & 24 & $21.92 \pm 0.73$ & 4.823 & & $0.000 *$ \\
\hline $\mathrm{BCT}$ & Non -Infected & 867 & $27.44 \pm 0.19$ & & & \\
\hline \multirow[t]{3}{*}{ PSANI } & T. Vivax & 8 & $20.63 \pm 0.18^{a}$ & & 11.952 & $0.000 *$ \\
\hline & T. Congolence & 16 & $22.56 \pm 1.06^{\mathrm{a}}$ & & & \\
\hline & Non- Infected & 867 & $27.44 \pm 0.19^{b}$ & & & \\
\hline
\end{tabular}

$\overline{\mathrm{a}, \mathrm{b}}$ The value across the column with different superscript are significantly different to each other $(\mathrm{P}<0.05)$. BCT

$=$ Buffy Coat technique, PSANI= Parasite species and Non-Infected.

Table 4: Apparent density of flies caught during the study period

\begin{tabular}{|c|c|c|c|c|c|c|c|c|c|c|c|c|}
\hline \multirow[b]{3}{*}{$\begin{array}{l}\text { Study } \\
\text { Sites }\end{array}$} & \multirow{3}{*}{$\begin{array}{c}\text { No. } \\
\text { of } \\
\text { PA's }\end{array}$} & \multirow[b]{3}{*}{$\begin{array}{l}\text { Altitude } \\
\text { Range }\end{array}$} & \multirow[b]{3}{*}{$\begin{array}{l}\text { No. } \\
\text { Traps }\end{array}$} & \multirow[b]{3}{*}{$\begin{array}{l}\text { No. } \\
\text { Days }\end{array}$} & \multicolumn{6}{|c|}{ Glossina Species } & \multirow[b]{3}{*}{ Total } & \multirow{3}{*}{ F/T/D } \\
\hline & & & & & \multicolumn{2}{|c|}{$\begin{array}{l}\text { Glossina } \\
\text { morsitans }\end{array}$} & \multicolumn{2}{|c|}{$\begin{array}{l}\text { Glossina } \\
\text { Fuscipes }\end{array}$} & \multicolumn{2}{|c|}{$\begin{array}{l}\text { Glossina } \\
\text { Palidipes }\end{array}$} & & \\
\hline & & & & & $\mathbf{M}$ & $\mathbf{F}$ & M & $\mathbf{F}$ & M & $\mathbf{F}$ & & \\
\hline Nono & 3 & $1375-1500$ & 60 & 2 & 15 & 39 & 97 & 267 & 22 & 77 & 517 & 4.31 \\
\hline Gudaya- & & & & & & & & & & & & \\
\hline Bila & 2 & $1895-1993$ & 60 & 2 & 1 & 1 & 0 & 0 & 1 & 0 & 3 & 0.03 \\
\hline Total & 5 & & 120 & 4 & 16 & 40 & 97 & 267 & 23 & 77 & 520 & 1.08 \\
\hline
\end{tabular}

$\mathrm{F} / \mathrm{T} / \mathrm{D}=$ fly $/$ trap/ day 
Table 5: Summary of trypanosomosis prevalence studies in different parts of Ethiopia

\begin{tabular}{|c|c|c|c|}
\hline Author (Year) & Part of the Country & Area/district & $\begin{array}{l}\text { Prevalence } \\
(\%)\end{array}$ \\
\hline $\begin{array}{l}\text { Abebayehu \& Biniam } \\
(2010)\end{array}$ & $\begin{array}{l}\text { Bench Maji zone, South } \\
\text { Western Ethiopia }\end{array}$ & Guraferda and Sheko & 4.4 \\
\hline Melkamu et al. (2017) & $\begin{array}{c}\text { Gurage Zone, Southern } \\
\text { Ethiopia }\end{array}$ & Edja & 5.25 \\
\hline Feyisa et al. (2011) & $\begin{array}{l}\text { Wolayta zone, Southern } \\
\text { Ethiopia }\end{array}$ & Humbo & 6.3 \\
\hline Gona et al. (2016) & $\begin{array}{c}\text { Wolaita zone, Southern } \\
\text { Ethiopia }\end{array}$ & $\begin{array}{l}\text { Humbo, Duguna Fango, Damot } \\
\text { Woyde }\end{array}$ & 6.7 \\
\hline Tafese et al. (2012) & $\begin{array}{c}\text { East Wollega zone, Western } \\
\text { Ethiopia }\end{array}$ & Diga and Sasiga & 8.55 \\
\hline Bitew et al. (2011) & West Gojjam zone & Jabi Tehrain & 11.7 \\
\hline Feyisa et al. (2019) & South Western Ethiopia & Botor Tulay & 12.24 \\
\hline Kumela et al. (2018) & Western Ethiopia & Dale Wabera & 12.28 \\
\hline
\end{tabular}

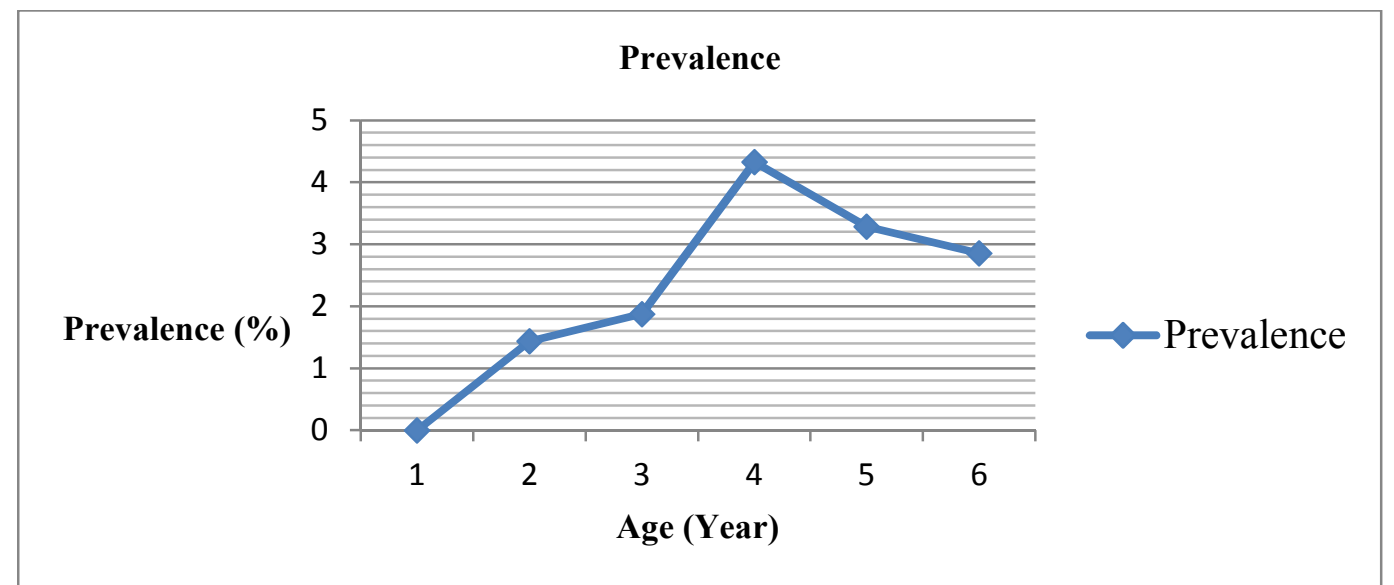

Figure 1: Prevalence of Trypanosomiasis associated to different age groups of cattle in the study area 